\title{
El brillo agustiniano acrisola los lienzos de Murillo
}

\author{
Pablo Antonio Morillo Rey \\ Centro de Estudios Teológicos de Sevilla
}

\begin{abstract}
Resumen: Es, sin duda, Bartolomé Esteban Murillo uno de los pintores sevillanos con más relevancia universal. Y precisamente este año, en el que nos hallamos celebrando el cuarto centenario de su nacimiento, presentamos este trabajo en el que deseamos mostrar cómo también en sus cuadros se plasmó la figura y el pensamiento de aquel gran santo y Doctor de la Iglesia que es conocido incluso por quienes ignoran el cristianismo o no tienen familiaridad con él. De esta forma, instamos al lector a descubrir, a través de dicho trabajo, cómo el brillo de San Agustín de Hipona acrisola también los lienzos que el maestro sevillano pintara para el convento agustino de su ciudad natal.
\end{abstract}

\begin{abstract}
Undoubtedly,Bartolomé Esteban Murillo is one of the Sevillian painters with the highest international impact. This year, the celebration of his $4^{\text {th }}$ Centennial, we present this paper about how he showed in his paintings the figure and thoughts of one great Saint who is Doctor of Catholic Church and who is well known even for those who ignore the Christianism. We refer to St. Augustine from Hipona and we invite the readers to discover how the bright of this saint is also reflected in the paintings that Murillo made for the Augustine Convent in his born city.
\end{abstract}

\section{INTRODUCCIÓN}

El presente trabajo, contextualizado en el año que conmemoramos el IV centenario del nacimiento de Bartolomé Esteban Murillo (1617-1682), pretende ofrecer -además de ciertas cuestiones -o nociones- referentes a la concepción estética agustiniana- una amplia visión sobre los principales y fundamentales temas tanto de la filosofía como teología agustinianas que han sido plasmados por el pintor sevillano. Para ello, se han tomado como referentes ciertas obras pictóricas que pertenecieron en otro tiempo al antiguo convento o Casa Grande 
de San Agustín (1292-1835) ${ }^{1}$ en Sevilla, y que actualmente se hallan depositadas en el Museo de Bellas Artes de la capital andaluza.

Igualmente, se alude y analizan otras dos obras más expuestas en distintos Museos españoles², y cuya temática agustiniana también centrará nuestra atención.

Y por último, no podíamos obviar en nuestro estudio la representación pictórica del dogma más relevante y crucial en la vida de la Iglesia: la Inmaculada Concepción de María, promulgado por el beato Pío IX (1846-1878) el 8 de Diciembre del año $1854^{3}$.

Precisamente, será este maestro sevillano quien reciba el sobrenombre o apelativo del "pintor de la Inmaculada"4, una "verdad de fe" ésta que ya sería también atisbada por"el Padre más grande de la Iglesia latina" ${ }^{5}$, como recogerá en algunas de sus obras ${ }^{6}$.

De crucial importancia será la referencia al tratado estético De pulchro et apto, perteneciente a su período juvenil. No obstante, las noticias que sobre éste poseemos son escasas y escuetas, pues incluso llega a perdérsele al mismo autor. Es por ello que su reconstrucción resulta ser una tarea bastante ardua y compleja, siendo muy curioso el olvido, el descuido o la indiferencia (intencionada o no) del obispo hiponense

Quizás, una de las posibles causas de todo esto sea su cambio de parecer en la noción estética, es decir, de un concepto totalmente pagano (al modo de los antiguos griegos) a otro cristiano (considera que el único artista que podrá poseer en el mundo dicho calificativo será el Dios Creador, Uno y Trino).

Mención aparte merece el arte musical para el obispo de Hipona. Así, recordamos el papel de las denominadas "artes liberales"7 en toda la Edad Media, al igual que el tratado agustiniano De música (389).

Por lo tanto, será a través de diez apartados que el lector -apoyándose para ello en algunas obras de Murillo- podrá realizar un breve recorrido por los principales temas que constituyen el sistema teológico del prelado de Hipona, así como ciertas cuestiones relevantes dentro de su filosofía estética.

De esta forma, asidos a las manos de ambos"genios", emprendamos nuestro apasionante y edificante recorrido por las sendas de la belleza plasmada y elaborada.

1 Se encontraba situado a extramuros, al este de la ciudad, cerca de la denominada Puerta de Carmona y al acueducto romano (vulgo "Caños de Carmona") que abastecía de agua a Sevilla, comprendido entre el tramo que discurría por la actual Calle Oriente.

2 Museo de Bellas Artes, deValencia y Museo del Prado, de Madrid.

3 Dogma recogido en la bula Ineffabilis Deus.

4 Se conocen cerca de veinte cuadros con el tema de la Inmaculada Concepción.

5 Benedicto XVI. Audiencia General, 9 Enero de 2008.

6 De natura et gratia (401) y De Genesi ad litteram (405-415).

7 Son siete en total: Gramática, retórica y dialéctica (trívium) y aritmética, música, astronomía y geometría (quadrivium). Aparecen por vez primera en la obra Sobre las bodas de Mercurio y la filología (410), de Marciano Capella (362-428). 


\section{LA ESTÉTICA DEL ARTE: ¿IMITACIÓN O RAZÓN? LA BELLEZA DIVINA COMO GRADO SUPREMO DEL GOCE ESTÉTICO}

"Pues veo que la imitación tiene tanta importancia en las artes que, si se la suprime, morirían casi todas ellas" ${ }^{\prime 8}$.

De todos es conocido que serán los libros de los platónicos, como él mismo asegura en su obra Confesiones $(397 \approx 400)^{9}$ un claro y notable influjo en todo el sistema filosófico de San Agustín de Hipona (354-430).

De igual manera, compartirá con el fundador de la Academia su noción de estética, de belleza o arte, aunque con una cierta matización cristiana.

Recordemos que para Platón (427-347 a. C) el arte -ya sea a través de todas sus expresiones (poesía, arte pictórico o plástica)- sólo puede ser entendido desde el punto de vista ontológico como una mera mímesis una imitación de acontecimientos sensibles (hombres, casas, hechos y cuestiones de distintas índoles). Por tanto, no puede ni debe ser considerado como fuente de conocimiento, ya que lo único que hace es velar la verdad al hombre, no desvelársela. ${ }^{10}$

No ejerce alguna utilidad a la hora de educarlo, de mejorarlo, pues tan sólo lo corrompe, lo engaña, ya que se dirige a la parte menos noble del alma, a lo irracional, a lo más ínfimo de nuestro ser.

Por todo ello, resultará bastante comprensible que el filósofo ateniense desee separarla, o incluso eliminarla, del Estado ideal que propone ${ }^{11}$. No obstante, sí podrá ser admitido cuando se someta a las leyes de lo bueno y lo verdadero, es decir, cuando se subyuga al saber filosófico.

En San Agustín, la sensibilidad estética irá tomando paulatinamente un matiz más espiritual, algo que lo hará remontarse hasta el Artífice-Creador. Así, logrará que su filosofía estética adquiera un sentido denotadamente religioso $\mathrm{y}$-como apuntamos anteriormente- cristiano.

De esta forma, hemos de advertir que para"el heredero de Mónica"12 , sólo será Dios Padre el único capaz de crear, ya que toda realidad puede proceder de otra a través de:

1) Por Generación: La sustancia procede del que la genera, constituyéndose por tanto en algo idéntico al que lo engendra. Un claro ejemplo nos vendría dado por la generación del hijo por parte del padre.

2) Por Fabricación: Dicho proceso surge de todas aquellas causas que el hombre produzca por sí mismo. Así, lo que se fabrica procede de algo

mus $I, 4,6$.

conf. VIII, 2,3.

"el arte mimético está sin duda lejos de la verdad" (Rep. X, 598b).

"Y así también es en justicia que no lo admitamos en un Estado que vaya a ser bien legislado"(Rep. X, 605b).

Francisco. Homilía durante la Santa Misa de apertura del capítulo general de la Orden de San Agustín, 28 Agosto de 2013. 
que ya existía previamente, aunque se halle fuera del que lo fabrique. Un ejemplo sería el mueble.

3) Por Creación: No procede ni de la propia sustancia ni tampoco de una sustancia externa. Ejemplo de ello sería la creación del mundo.

Por lo tanto, no podrá existir nada en el mundo que no sea obra de dicho Creador, pues "Ciertamente, no puede existir nada que no tenga un Creador"13. Así mismo, dicha creación también participa de la idea de belleza, ya que"de El y en El tienen todas las cosas su belleza perfecta e inmutable"14.

En conclusión, toda naturaleza creada se transforma en una maravillosa sinfonía del Creador, un Dios Creador al que se le considera como el auténtico artista, y que es contemplado como la belleza Fontal o primera. Por todo lo cual, la actividad artística del ser humano no será más que una participación de dicho acto creador divino.

Y surgirá de esta manera la diferenciación entre la belleza natural (Creador) y la artística (hombre), siendo la primera de éstas la que -personalmente- más le emocionaba (belleza cósmica):

"Mirad este mundo: tiene su hermosura. ¡Qué belleza encierran la tierra, el mar, el aire, el cielo, los astros! Todas estas cosas, ¿no abruman con su estupor toda consideración? Y su hermosura, ¿no llega a tanto que ya no pueda hallarse nada que la supere?"15.

Así, dicha"emoción estética" despertará un placer legítimamente distinto al de la concupiscencia, pues "el supremo goce estético" se hallará en la contemplación de la belleza divina.

De esta forma, queda patente que es la búsqueda de la verdad, de Dios, la clave central de todo el amplio sistema filosófico agustiniano, de la cual el arte sólo será mera apariencia:

“...porque la belleza que a través del alma pasan a las manos del artista vienen de aquella belleza que está sobre las almas y por la cual suspira la mía día y noche"16.

Pero, por otro lado, sin olvidar a la imaginación como facultad creadora, el arte constituye para "el genio de Europa"17 una actividad más racional que romántica. Para él, dicha facultad se hará presente -fundamentalmente- en la poesía, pintura y escultura, artes estas dos últimas por las que siente muy poca estima, ya que ambas se reducen a imitar y copiar la realidad con un escaso éxito.

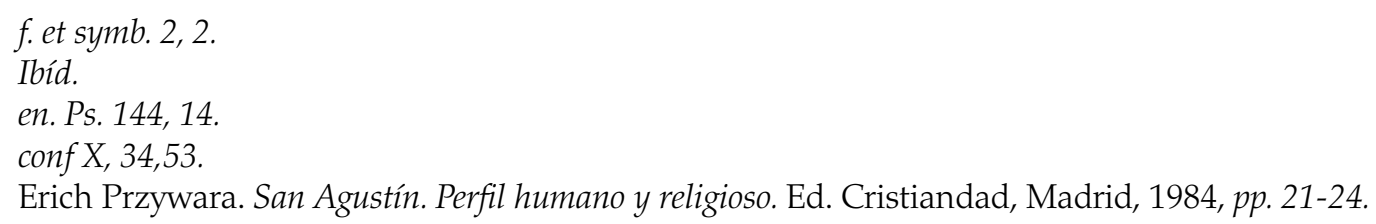


"Por tanto -asevera San Agustín- quien no se sirve de la razón no hace uso del arte". ${ }^{18}$

Así, la belleza incorpórea, ubicada más allá de la belleza natural y artística, sólo será accesible a la razón (ratione).

El ser humano, además de percibir, comprender y conocer la belleza, deberá ofrecer un juicio sobre lo bello (juicio estético), algo que atañe a los sentidos y en último lugar a la razón. Esto resulta ser comprensible si tenemos en cuenta que es el alma -el"sujeto estético"- la que capta y aprecia lo bello, la cual a su vez no es sino la"casa" de aquélla, puesto que"Si el alma es un sujeto, en el que la razón reside inseparablemente..."19.

De esta forma, tanto la razón como el ingenio serán, indistintamente, fuentes de creación para la Edad Media, algo que -sin duda- viene a conectar y a continuar la"infatigable unión entre la fe y la razón"20.

Es la racionalidad colaboradora indispensable para que el arte deje de ser una pura imitación, pues dicho arte constituye un canal de emisión y transmisión silente para el ser humano, el sujeto dotado y adornado con razón ${ }^{21}$.

Por ello, el hombre -gracias a ésta- podrá adquirir conocimiento, un conocimiento que -como él mismo nos indica- podrá ser de dos tipos o clases posibles: 1) sensorial (hará referencia al sujeto sentiente) y 2) racional (hará referencia al sujeto pensante $)^{22}$.

Por tanto, se podría concluir afirmando que en el arte" cabalgan simultáneamente"la imitación y la razón, la mímesisy la ratio, la facultad imitativa y la facultad racional, ya que si la creación es "la única y verdadera obra de arte"-así como el auténtico Artista es el Creador- , todas las demás (obras de arte) resultarán ser imitaciones o copias de aquélla. Pero, por otro lado, dicha obra de arte constituye a la vez un medio de comunicación eficaz para todo sujeto dotado de razón, de un alma racional (razón ésta por la que el animal no puede producir arte).

\section{SAN AGUTÍN LAVANDO LOS PIES A CRISTO: “LA IGLESIA TIENE NECESIDAD DE LAVAR LOS PIES" (Jo.ev.tr. 56, 5)}

"Si quieres verte libre, por la gracia del Señor, de tus numerosos y grandes pecados, y deseas purificarte en la Iglesia de tu inmunda prostitución, cree, acércate a los pies de Jesús, busca sus huellas, riégalos con tus lágrimas y límpialos con tus cabellos...

20 De lo cual San Agustín de Hipona fue pionero, puesto que "Credo ut intelligam et intelligo ut credam" (s. 43, 4).

21 "es el único entre los animales que posee razón". Aristóteles, Política VII, 12,1332b.

22 Trin. XI, 9,16. 
Limpia, pues, los pies de Jesús, sécalos totalmente, haciendo obras de misericordia, y después de secarlos, bésalos; recibe la paz, y conseguirás la caridad"23.

Así, a imitación de la pecadora perdonada ${ }^{24}$, cada uno de nosotros tenemos, debemos y hemos de lavar los pies a Cristo, en los cuales quedan representados todos los predicadores del Evangelio ${ }^{25}$. De esta forma, en este gesto queda demostrado la necesidad de la humildad, de la noble y leal sencillez con la que todo cristiano deberá ser adornado, pues:

"Alto es Dios, abájese el cristiano. Si quiere que el alto se acerque a él, humíllese. Grandes misterios son éstos, hermanos. Dios está por encima de todas las cosas; tú te empingorotas, y no le tocas; te humillas, y Él desciende a ti"26.

Por todo ello, dicha humildad -el fundamento de toda perfección cristianadeberá ser como el" peldaño", el" primer escalón" ${ }^{27}$ que nos ayude a subir hasta Dios. Pero:

"Este camino de la humildad mana de otra fuente: viene de Jesucristo. En efecto, al humillarse, haciéndose obediente hasta la muerte, y muerte de $\mathrm{cruz}^{28}$, ¿qué otra es la significación al pagar la deuda, que él no había contraído para librarnos a nosotros de la nuestra?.... Todo esto, ¿qué otro fin tenía sino enseñarnos la humildad?"29

No obstante, como bien advierte"el gran enamorado de Dios" 1 , ésta no es más que el conocimiento de sí mismo ${ }^{31}$, algo que -sin duda- podría recordarnos a la ya conocida sentencia atribuida a Sócrates (470-399 a. C) del“Conócete a ti mismo" (gnóthi seautón/ nosce te ipsum) ${ }^{32}$.

Sin embargo, "nada de esto (humildad) se encuentra en los libros no cristianos, ni en los epicúreos, ni en los estoicos, ni en los maniqueos, ni en los platónicos"33.

Así, este tan gran santo e ilustre varón -por cuya sangre Dios fluía- entendió que su misión (apoyado en el saber filosófico) no era otra que hacer entrar al hombre dentro de sí mismo para ayudarle a ver lo que le falta, a la vez que hacerle despertar de sus fallos, pues deberá afianzarse sobre la roca de la verdad para no

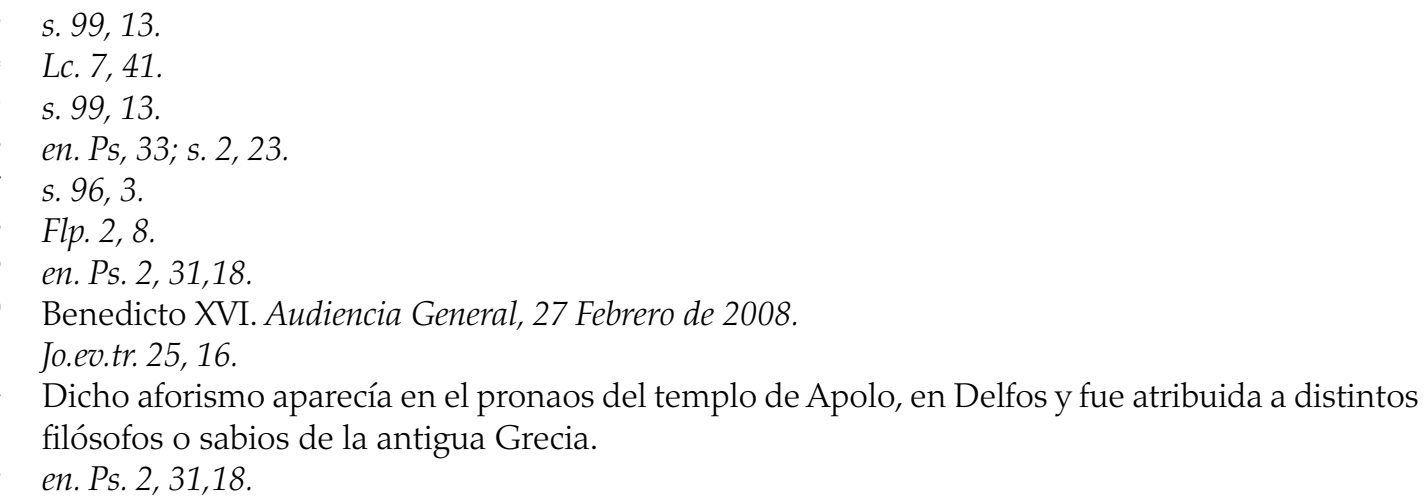


ser derribado por los huracanes de esta vida. Es con esto que surge el denominado "principio de interioridad", el cual analizaremos en el siguiente apartado.

\section{SAN AGUSTÍN ENTRE CRISTO Y LA VIRGEN: “CRISTO-VERDAD ESTABA EN LA MENTE DE MARÍA, CRISTO-CARNE ESTABA EN EL SENO DE MARÏA" (s. 72A, 7)}

"Dime adónde tengo que mirar para verte...." 34 , pero"no como lo vieron los judíos, y lo crucificaron, sino como lo ven los ángeles, y se gozan"35.

Así, y como se desprende de los textos precedentes, el deseo del "padre común de la Europa cristiana" 36 era el poder ver y contemplar a Dios, puesto que -como bien señalara en su obra Confesiones-"Nos hiciste para ti, y nuestro corazón está inquieto hasta que descanse en ti"37.

Es hacia El y por El al que todos los hombres lanzan sus miradas, amándolo intensamente, a veces sin saberlo. De esta forma:

"Cualesquiera filósofos que sintieron esto del sumo y verdadero Dios. que es autor de las cosas creadas, y luz de las que se deben conocer, y bien de las que se deben hacer, y que es para nosotros el principio de nuestra doctrina y la felicidad de nuestra vida; ora se llamen platónicos, ora tenga su escuela otro nombre, son los que se llevan nuestra preferencia sobre los demás y confesamos que son los que más se han acercado a nosotros ${ }^{\prime 38}$.

Por todo lo cual, resulta ser también la filosofía un "instrumento útil", "un medio eficaz" para poder conocer a la suma y eterna Verdad. De esta forma, Romano Guardini (1885-1968) elabora y ofrece una nueva interpretación que, a continuación, reproducimos:

"así, como tercera interpretación se ofrece la desarrollada desde la perspectiva de la historia del pensamiento. Esta tiende a no ver en la "conversión" de Agustín un paso hacia el cristianismo, sino sólo hacia la "vita beata" filosófica del "Hortensio" o del neoplatonismo. Sólo después, bajo la influencia del estudio de la Escritura y de la actividad sacerdotal, surgió según esta visión lo auténticamente cristiano y se realizó, esta vez sí, como una suerte de la segunda conversión a la palabra de Dios y a la fe. Desde esta nueva posición, Agustín arrojó después una mirada retrospectiva a su vida, introdujo interpretativamente la segunda conversión en la primera, y así surgieron las"Confesiones"'I"'39.

Sol. $1,1$.

en. Ps. 84, 9.

San Juan Pablo II. Augustinum Hipponensem II.

conf. $I, 1,1$.

civ. Dei VIII, 9.

39 Romano Guardini. La conversión de Aurelio Agustín. El proceso interior en sus Confesiones. Ed. DDB, Bilbao, 2013, p. 13. 
No obstante, será a través de ésta -“su obra más famosa"y“escrita para alabanza de Dios" ${ }^{40}$ - que el obispo de Hipona centre su atención tanto en la interioridad (influencia plotiniana) como en la psicología, gracias a las cuales (y según Benedicto XVI (2005-2013)) se constituiría en "un modelo único en la literatura occidental, y no sólo occidental, incluida la no religiosa, hasta la modernidad" ${ }^{41}$.

Por lo tanto, "Dios ha de ser buscado e invocado en lo secreto del alma racional, que se llama el hombre interior" ${ }^{42}$.

Así si recordamos, la filosofía agustiniana consta de tres principios básicos, siendo uno de éstos la mencionada interioridad (participación e inmutabilidad serán los otros dos restantes). Dicho principio es descubierto por el obispo africano gracias a la lectura de los neoplatónicos, en concreto Plotino (205-270) quien predicaba la necesidad de tener que retirarse al interior de uno mismo -apartándose así de todo lo externo- para poder hallar la verdad dentro del alma ${ }^{43}$. Pero, dentro de dicha interioridad podremos encontrar, a su vez, y según Guardini ${ }^{44}$, distintos "tipos u ámbitos". De esta manera, tenemos:

1) La propia del niño pequeño, el cual encerrado en sí mismo resulta ser preso de sus deseos y necesidades, incapaz de hablar y de poder llegar hacia los adultos que se hallan fuera, como él mismo relatará en las Confesiones:

"Poco a poco me iba dando cuenta de dónde estaba, y quería manifestar mis deseos a quienes me lo podían satisfacer, aunque realmente no podía, porque los deseos estaban dentro y aquellas personas fuera $y$, por ninguno de sus sentidos podían entrar en mi alma. Por eso, agitaba mis miembros y daba gritos, signos semejantes a mis deseos, los pocos que podía y como podía, aunque no eran verdaderamente muy expresivos. Y cuando no se me complacía o porque no me habían entendido, o porque no me convenía, me indignaba: con los mayores, porque no se me sometían, y con las personas libres porque no me servían. Y de unos y otros me vengaba llorando" ${ }^{\prime 4}$.

2) La interioridad existente en el adulto entre la lucha moral y religiosa, y de la propia decisión personal. Ésta separa a la persona de todas aquellas otras que son externas al propio individuo:

“Buscaba ansioso de dónde procedía el mal. ¡Qué dolores de parto los de mi corazón! ¡Qué gemidos, Dios mío! Allí estaban tus oídos sin saberlo yo.Y mientras en silencio yo te buscaba con ahínco, las calladas congojas de mí espíritu eran grandes voces ante tu misericordia. Sólo tú sabías lo que yo sufría. No lo sabía

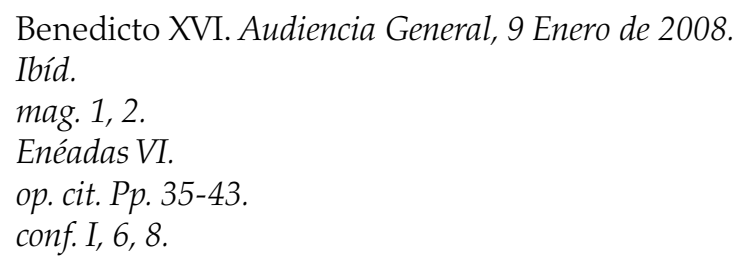


ningún hombre. Porque de estas cosas, ¿cuánto era lo que mi lengua comunicaba a los oídos de mis más íntimos amigos? ¿Acaso sonaba en ellos todo el alboroto de mi alma, que ni el tiempo ni las palabras bastaban para expresarlo? Sin embargo, todo llegaba a tus oídos, lo que yo rugía con el gemido de mi corazón, y delante de ti estaba mi deseo, y la luz de mis ojos no estaba conmigo. Porque la luz de mis ojos estaba dentro y yo fuera; ella no ocupa lugar". ${ }^{46}$

3) La denominada"interioridad negativa", consistente en desear ocultar el "yo maligno", el no querer ver lo que debe ver:

"Contaba Ponticiano estas cosas, y mientras él hablaba, tú, Señor, me hacías replegar y entrar en mí mismo, quitándome de mis propias espaldas, en las que yo me había instalado porque no quería verme, y me ponías delante de mis ojos, para que viese qué feo, qué deforme, qué sucio, manchado y ulceroso estaba. Me horrorizaba el verme así, pero no tenía a dónde huir de mí. Pues si intentaba apartarme de mí mismo la mirada, con el relato que Ponticiano iba narrando, de nuevo tú persistías en que me enfrentara conmigo mismo y ponías viva luz en mis ojos para que viera mi fealdad y la aborreciera. Ya la conocía yo, pero la disimulaba, reprimía y me olvidaba de ella" ${ }^{\prime 4}$.

4) Aquella que aparece como fruto de la tensión entre el deber y el obedecer de la propia voluntad:

"Porque no sólo el ir, sino el mismo llegar a Dios no consistía en otra cosa que en querer ir; pero querer fuerte e íntegramente, no a medias, no traer y llevar de acá para allá la voluntad enfermiza, en la que lucha la parte que se eleva contra la otra parte que se hunde" 48 .

\section{5) Interioridad del acto religioso:}

"Apenas doblamos las rodillas con suplicante afecto, huyó aquel dolor: ¡y qué dolor! ¡y como huyó! Quedé atónito, lo confieso, Dios mío y Señor mío, porque nunca desde mi primera edad había experimentado cosa semejante. Y, en lo más profundo de mi ser me hiciste sentir el poder de tu voluntad; y lleno de gozo en la fe, alabé tu nombre" ${ }^{\prime \prime}$.

6) Interioridad espiritual:

"Pero tú estabas más dentro de mí que lo más íntimo mío y más alto que lo más alto de mi ser" ${ }^{\prime 50}$.

6 conf.VII, 7, 11.

conf. VIII, 7, 16 .

conf. VIII, 8, 19 .

conf. IX, 4,12 .

conf. III, 6,11 . 
7) Interioridad cristiana, otorgada al hombre por el Espíritu Santo:

"¡Tarde te amé, hermosura tan antigua y tan nueva, tarde te amé! Y he aquí que tú estabas dentro de mí y yo fuera, y por fuera te buscaba, y sobre estas cosas hermosas que tú creaste me arrojaba deforme. Tú estabas conmigo, pero yo no estaba contigo. Lejos de ti me retenían aquellas cosas que, si no estuviesen en ti, no existirían. Me llamaste y más tarde me gritaste, y rompiste finalmente mi sordera; brillaste y resplandeciste, y ahuyentaste mi ceguera, exhalaste tu perfume, lo inhalé en mi respiración, y ahora suspiro por ti, gusté de ti, y siento hambre y sed; me tocaste, y me encendí en deseo de tu paz"51.

8) Interioridad divina (supra-interioridad):

“¿Dónde, pues, te encontré para conocerte? Porque ciertamente antes de conocerte no estabas en mi memoria. ¿Dónde, pues, te encontré para conocerte, sino en ti mismo y por encima de mí? Aquí no hay ningún lugar. Nos apartamos y nos acercamos, pero no hay lugar. Tú, que eres la verdad, ocupas un puesto de preferencia en todas partes para responder a los que te consultan. Y respondes a todos a la vez, aunque te consulten cosas diversas, Tú respondes claramente, pero no todos oyen claramente. Todos te consultan lo que quieren, pero no todos oyen siempre lo que quieren. El mejor servidor tuyo es aquel que no se empeña en oír de ti lo que a él le gustaría, sino el que está dispuesto a querer lo que tú le digas" ${ }^{52}$.

\section{SAN AGUSTIIN CON VIRGEN Y NIÑO: “UNA MUJER NOS ALUMBRÓ LA VIDA" (s. 184, 2)}

“Cristo, pues, nació del Espíritu Santo y de María Virgen...Hízose Hijo del hombre sin dejar de ser Hijo de Dios" ${ }^{\prime 53}$.

Para el hombre que "siempre buscaba el diálogo"54,la Santa Virgen María ${ }^{55}$ ejerció una "doble función": el ser Madre de Cristo y -por ende- de la Iglesia ("María, por tanto, haciendo la voluntad de Dios, es solo Madre de Cristo corporalmente,....; pero ciertamente María es Madre de sus miembros, que somos nosotros, porque cooperó con su caridad para que nacieran en la Iglesia los fieles...." $)^{56}$, una Madre a la cual Él mismo eligiese y predestinase:

conf. $X, 27,38$.

conf. $X, 26,37$.

s. 121,5 .

Benedicto XVI. Audiencia General, 16 Enero de 2008.

Título con el que gustaba llamar a María (nat et gt. 36, 43).

virg. 5, 5-6, 6 
"El Verbo, que desde siempre la había conocido, la reconoce entonces como Madre suya, al predestinarla, y, antes de que Él mismo como Dios crease a aquella de la cual sería creado Él como hombre, ya la conoce como Madre suya (...). El mismo Señor es Señor de María e Hijo de María"57, pues "Nuestro Señor Jesucristo, que existía junto al Padre, antes de nacer la Madre, no sólo eligió la virgen de quien había de nacer..." ${ }^{15}$

Por todo ello, María aparecerá como la Madre virginal y santa:

1) Virginal, algo que libremente Ella eligió y que -gracias a la omnipotencia divina- se mantendría incluso después del parto:

"María consagró su virginidad a Dios aun antes de saber que había de concebir a Cristo, para servir de ejemplo a las futuras santas vírgenes y para que no estimaran que sólo debía permanecer virgen la que hubiera merecido concebir sin el carnal concúbito. Imitó así la vida celeste en el cuerpo mortal por medio del voto, sin estar obligada; lo hizo por elección de amor y no por obligación de servidumbre. Por ello, Cristo al nacer de una virgen prefirió aprobar a imponer la santa virginidad a una virgen que, aún antes de saber quién había de nacer de ella, había ya determinado permanecer virgen. Y así quiso que fuese libre la virginidad hasta en la mujer en la que Él tomó la forma de siervo" 59 , puesto que"nació del Espíritu Santo y de la santa Virgen María, sobre la que actuó no un marido humano, sino el Espíritu Santo, quien fecundó a la casta, y la dejó intacta" ${ }^{\prime 60}$.

De esta forma nos dirá que:

"como en el sepulcro donde fue colocado el cuerpo del Señor no fue ni antes ni después enterrado cuerpo alguno, así el vientre de la Virgen ni antes ni después de la concepción del Señor concibió nada mortal" ${ }^{\prime 61}$.,

2) Santidad, algo que -sin duda- se deberá fundamentalmente a:

a) Hacer la voluntad de Dios, pues" ¿Acaso no hacía la voluntad del Padre la Virgen María que en la fe creyó, en la fe concibió...?"62

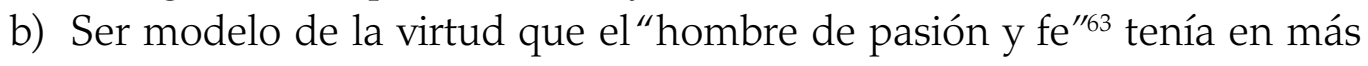
alto aprecio: la humildad, puesto que "Aunque había merecido alumbrar al Hijo del Altísimo, era muy humilde"64.

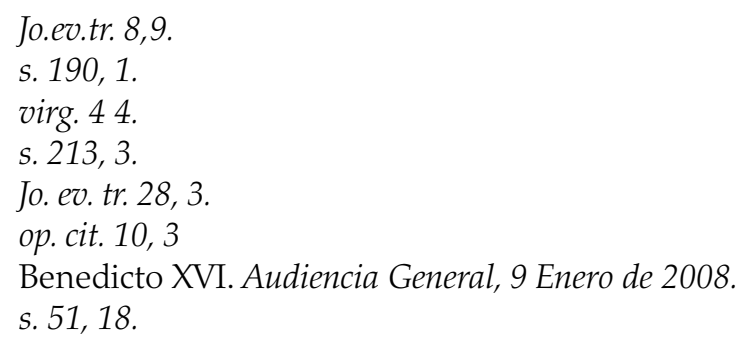




\section{VISIÓN DE SAN AGUSTÍN CON LA TRINIDAD: “POR TODAS PARTES TE RODEA MISERICORDIOSAMENTE LA PROVIDENCIA DIVINA" (s. 30, 4)}

Como bien sabemos, en la producción agustiniana es importante De Trinitate, obra en quince libros que versarán sobre el núcleo principal de la fe cristiana, la fe en el Dios Uno y Trino, escrita en dos tiempos: entre los años 399 y 412 los primeros doce libros, publicados sin él saberlo, siendo revisados y completados todos los libros hacia el año 420. En ésta reflexiona sobre el rostro de Dios, y trata de comprender este misterio, que es único, el único Creador del mundo, de todos nosotros: precisamente este Dios único es trinitario, un círculo de amor. Trata de entender el misterio insondable, pues precisamente su ser trinitario, en tres Personas, es la unidad más real y profunda del único Dios ${ }^{65}$.

Igualmente, el obispo de Hipona expone en dicho tratado -de un gran nivel teológico-cómo la mencionada Santísima Trinidad queda impresa y reflejada en cada ser humano. Así:

“Estas tres cosas, memoria, entendimiento y voluntad, no son tres vidas, sino una vida, ni tres mentes, sino una mente. En consecuencia, no son tres sustancias, sino una sustancia.... En sentido absoluto cada una de estas tres facultades es vida, mente y esencia. Luego en tanto son uno en cuanto son una vida, mente y esencia, y cualquier otra cosa que se predique de las tres en sentido absoluto" ${ }^{\prime \prime 6}$.

Pero, ¿qué entiende este hombre"de altísima inteligencia y de incansable solicitud pastoral" ${ }^{\prime 67}$ por Providencia?

Pues ésta -apunta Guardini- no era concebida sino como mero "actuar constante de Dios, un obrar la realidad, un disponer las interrelaciones, un ejecutar los acontecimientos" ${ }^{\prime \prime}$.

San Agustín es consciente de que -a veces- con el lenguaje humano resulta muy difícil y complejo el explicar la completa realidad de Dios, expresarla adecuadamente, pues desborda las palabras y los sentimientos. No obstante, tanto griegos (cuyas fórmulas son más imprecisas e insuficientes) como latinos se han esforzado por expresar dicha realidad divina, utilizando para ello las "diversas fórmulas literarias" que dichos lenguajes les permitían:

"Para expresar de algún modo lo que es imposible enunciar, nuestros griegos hablan de una esencia y tres sustancias; los latinos de una esencia o sustancia y tres personas" 69 .

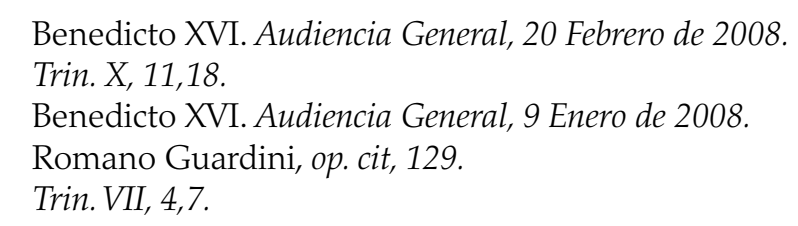


Sin embargo, se hable como se hable, nunca se debe perder de vista que en todo momento se hace referencia a una unidad, no a tres realidades diversas ("triteísmo"), puesto que "No perdáis de vista la unidad, si queréis evitar el escollo de la separación" 70 .

Por otro lado, en Dios resulta más adecuado el hablar de esencia y no de sustancia, pues "llamamos propiamente sustancia a los seres mudables y compuestos"71, lo cual es totalmente inadmisible hablando de Dios.

Además, en Él el ser y el subsistir no son dos realidades distintas, sino una sola, y al hablar de tres sustancias se podría correr el riesgo de pensar en tres esencias independientes (tres deidades). Así, el obispo africano prefiere emplear la fórmula de "una esencia y tres personas", pues así queda mejor expresada la realidad monotrina de Dios $^{72}$.

Pero, lo que queda suficientemente claro es que, para hablar de Dios se ha de hacer (en primer lugar) una profesión de fe en Él, puesto que "antes de entender es necesario creer" ${ }^{\prime \prime 3}$, ya que cuando se habla de Él es preferible la ignorancia piadosa a la ciencia presuntuosa ${ }^{74}$.

\title{
7. SAN AGUSTÍN Y LA INMACULADA CONCEPCIÓN DE MARÍA: “...LA MISMA MADRE DE NUESTRO SEÑOR Y SALVADOR....EXIGE QUE LA CONFESEMOS EXENTA DE PECADO" (nat et gr. XXXVI, 42)
}

\begin{abstract}
“Exceptuando, por tanto, a la santa Virgen María, sobre la cual, por el honor debido a nuestro Señor, no quiero tener ninguna discusión cuando se trata de pecados; porque sabemos que para vencer al pecado por todos sus flancos le fue dado más gracia a aquella que mereció concebir y alumbrar al que consta que no tuvo pecado alguno; repito: exceptuando a esta Virgen, si pudiésemos reunir y preguntar a todos aquellos santos y santas, cuando vivían aquí, si estaban sin pecado ¿qué pensamos que iban a responder? (...) "Si decimos que no tenemos pecado, nos engañamos, y la verdad no está en nosotros"( 1 Jn. 1, 8-9)"75.
\end{abstract}

Así, parece que -en el texto anterior- San Agustín enseña con toda probabilidad la Inmaculada Concepción de la Bienaventurada Virgen María.

No obstante, como bien se podría objetar, el obispo que "dejó una huella profundísima en la vida cultural de Occidente y de todo el mundo"76 no habla expresamente de "pecado original" en dicho texto, sino de "pecados". Sin

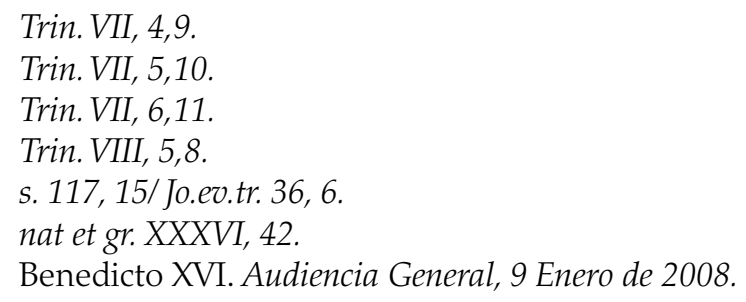


embargo, al expresar que ningún santo se halla libre de pecado personal -al cual considera como la"enfermedad contraída directamente a causa de dicho pecado original" - nos hace ver que: si a la Virgen no se le puede atribuir ningún pecado personal es puesto que se encuentra exenta de dicha"enfermedad", lo que justamente señala con la expresión "le fue dada más gracia".

Para San Agustín, es importante que dentro del plan de salvación de la humanidad se encuentre la santificación de la carne de María, pues tengamos en cuenta que de Ella nacerá el Salvador del mundo:

"Pues lo que (el Hijo de Dios) de nosotros tomó, o lo purificó antes de tomarlo, o lo purificó en el momento mismo de tomarlo. Para este fin creó a laVirgen, a la que había de elegir para que le diese el ser en su seno, y ella no concibió por la ley de la carne de pecado $(R m .8,3)$, o por la concupiscencia carnal, sino mereciendo por su piedad y por su fe que el santo germen se formase en sus entrañas"77.

Así, por tanto, no existe nada más limpio y exento de pecado que el seno de la santa Virgen María, la cual concibió a Cristo, al margen del pecado original, pues:

“¿Y qué hay más limpio de pecado que el seno de María, cuya carne, aunque viene de la propagación del pecado, sin embargo, no concibió de la propagación del pecado, de modo que aquella ley que, implantada en los miembros del cuerpo de muerte, repugna a la ley del espíritu, no contaminase el mismo cuerpo de Cristo?"78

Pero, el Doctor de la Gracia aún va más allá pues, considera a la Madre del Señor como partícipe de dicha santidad en el mismo momento de su nacimiento, ya que:

"Yo no entrego a María al diablo por la condición de su nacimiento, precisamente por eso, porque la misma condición de su nacimiento está resuelta por la gracia del renacimiento"79.

Y es dicha santidad algo tan valorado, tan ensalzado por San Agustín que, incluso, llega a colocarla por encima de la misma maternidad divina, como bien podemos desprender del siguiente texto:

"“Bienaventurado el vientre que te llevó" (Lc. 11, 27). Y el Señor para que no se buscase la felicidad en la carne, ¿qué respondió?"Mejor: Bienaventurados los que oyen la palabra de Dios y la cumplen" (Lc. 11,28). Por eso bienaventurada es María, porque oyó la palabra de Dios y la guardó. María guardó mejor la verdad en la mente que la carne en su seno. Porque Cristo es la Verdad: Cristo es carne. La Verdad-Cristo 
estaba en la mente de María; la carne-Cristo en el vientre de María. Más es lo que está en la mente, que lo que es llevado en el vientre" ${ }^{\prime 80}$.

Por todo ello, "Eres Virgen, María, eres santa, has hecho un voto pero es muy grande lo que has merecido, mejor, lo que has recibido" ${ }^{\prime 81}$.

\section{EL AMOR: PUENTE QUE ATRAVIESA EL RÍO DE LO BELLO}

"Quien conoce la verdad conoce aquella luz, y quien conoce aquella luz conoce la eternidad. El amor es lo que conoce" ${ }^{\prime \prime 2}$.

En primer lugar, hemos de advertir que el amor es algo connatural al ser humano, puesto que será quien determine su esencia, es decir, lo que es, ya que como bien dirá San Agustín:“En verdad, para saber lo que es un pueblo hay que preguntarle qué ama" ${ }^{\prime 3}$.

Por todo ello, el hombre es exhortado a amar, debe amar, aunque teniendo bien en cuenta qué es lo que ama. Así, el mismo arte, lo bello y armonioso, puede conducirnos al goce de lo divino, creador de toda armonía:

“ ¿Os digo acaso que no améis? ¡Dios me libre! Si no amáis nada, seréis perezosos, dignos de ser aborrecidos, miserables, estaríais muertos. Amad, pues, pero ¡cuidad bien lo que amáis!"84

Es esto una gran diferencia respecto a los filósofos griegos, pues ya el hombre no será aquél que sepa y conozca, sino -ante todo- el que ame. No obstante, habrá de tener muy en cuenta que no todo amor es "bueno", pues "todo amor o sube o baja; con el buen amor subimos a Dios, con el mal amor caemos en el despeñadero" ${ }^{\prime \prime 5}$.

Pero, ¿cuál es este amor que "sube"? ¿Y el que "baja"? Así, uno de éstos podrá conducirnos también al goce de lo divino, a la visión plena y beatífica, mientras que el otro nos hundirá en todos los males:

"la raíz de todos los males es cupiditas; la raíz de todos los bienes es caritas" 86 , ya que "caritas es de hecho una mediación entre hombre y Dios, de la misma manera que cupiditas lo es entre hombre y mundo" ${ }^{87}$.

S. 72 A, 7.

s. $291,5-6$.

conf. VII, 10, 16.

civ. Dei XIX, 24

en. Ps. XXXI, 2, 5.

en. Ps. $122,1$.

en. Ps. 90, 1,8.

Hannah Arendt. El concepto de amor en San Agustín. Ed. Encuentro, Madrid, 2001, p. 49. 
De esta forma, el amor -ese" movimiento del alma que nos conduce a gozar de Dios por El mismo, y de nosotros y del prójimo por Dios" ${ }^{88}$ - desempeña, a veces, el papel de "puente" a través del cual atraviesa lo bello y sublime. Por todo ello, el obispo de Hipona exhortará a que:

"Ama y haz lo que quieras. Si callas, calla por amor. Si gritas, grita por amor. Si corriges, corrige por amor. Si perdonas, perdona por amor. Exista dentro de ti la raíz de la caridad; de dicha raíz no puede brotar sino el bien"1"89.

Pero, San Agustín también nos proporciona un criterio preciso para dicho amor, estableciendo la distinción entre el uti y el frui. De esta forma, los bienes finitos serán usados como medios, pero nunca se podrán transformar en objeto de fruición y gozo, al igual que si fuesen fines.

Es por ello que ya la virtud del ser humano es considerada en función del amor y no del conocimiento, como sí habían hecho los filósofos griegos antaño. Así, aquélla no consistirá más que en amarse tanto a sí mismo como a los demás o a las cosas no según el juicio humano, sino el divino, pues cada una de éstas posee una dignidad ontológica propia y distinta. Es en esto en lo que consiste el "amar de una manera justa".

Por otro lado, la misma fe nos enseña que hay actos -como la creación y la redención- que no son sino productos del amor, de la donación de sí.

Por todo ello, no podemos concluir sino afirmando que será dicho amor el que otorgue consistencia tanto al hombre en sí como a su destino mundanal y trascendental, pues

"Pondus meum, amor meus"90.

\section{EL BRILLO DE LA ESTÉTICA: DE PULCHRO ET APTO}

"...y escribí unos libros sobre"lo hermoso y lo apto", creo que dos o tres -tú lo sabes, Señor- , porque lo tengo ya olvidado y no lo conozco por habérsenos extraviado no sé cómo" ${ }^{\prime \prime 1}$.

De esta forma, San Agustín compone -contando con "unos veintiséis o veintisiete años cuando escribí aquellos volúmenes" ${ }^{\prime 22}$ - su primer ensayo, del cual nada más sabemos. Así, resulta muy extraño esta "despreocupación" por"el primer fruto de su ingenio", pues ni él mismo en sus Retractationes (426-427)

doc. Chr. III, 10,16.

Jo. ev. tr. 7,8 .

conf. XIII, 9.

conf. IV, 13,20.

conf. IV, 15,27. 
ni tampoco San Posidio (¿?) (discípulo de San Agustín y obispo de Calama, en Numidia (África)) en su Indiculo librorum eius, lo mencionan.

No obstante, sí podemos suponer tanto las ideas como el carácter que dominaba en éste, dado el materialismo que, por aquel entonces, embargaba su alma, ya que" ...revolviendo dentro de mí puras imágenes corporales, cuyo ruido aturdía los oídos de mi corazón" ${ }^{\prime 93}$.

Por otro lado, el mismo santo nos asegura que dicho escrito fue dedicado a "Hierio, retórico de la ciudad de Roma, a quien no conocía de vista, sino que lo amaba por la fama de su doctrina, que era grande, y por algunos dichos suyos que había oído y me agradaban"94.

Tampoco podemos saber con certeza de quién se trata, así como cuál sería el juicio que aquél emitiese sobre dicho ensayo, aunque -al juzgar por la simpatía que el maestro de Tagaste muestra hacia éste- parece fue bien recibido y aplaudido:

"Sin embargo, yo revolvía en mi mente y contemplaba con regusto aquel tratado mío sobre"Lo hermoso y apto" ....."

De esta manera, a través de dicho tratado lo único que "este espíritu tan grande" 96 perseguía era la gloria terrena, el aplauso, la alabanza justa, noble y merecida, la cual le proporcionaría su fama y su posterior conquista de discípulos, pero:

“...así era yo; ni me avergüenzo ahora, Dios mío, de confesar tus misericordias para conmigo y de invocarte, ya que no me avergoncé entonces de profesar ante los hombres mis blasfemias y ladrar contra ti...Nuestro bien vive siempre contigo, y así, cuando nos apartamos de él, nos pervertimos ("aversisumus, perversi sumus")"197.

Dicho tratado -aunque como ya hemos advertido anteriormente- se perdió, no así el espíritu que lo animaba, pues -seguramente- sería éste la fuente o el criterio de donde procediesen los datos, ideas y apreciaciones estéticas que habrían de ser"repartidas" por las demás obras agustinianas. Por ello, la línea de inspiración seguida en éste sería la platónica-plotiniana, haciendo hincapié a la vez sobre los aspectos de relación y unidad como elementos integrantes de la belleza objetiva.

Por todo lo cual, San Agustín nunca abandonó su alto sentido de dicha belleza, aunque si bien expresada en distintas formas a medida que iba cambiando su concepción acerca del mundo y la vida.

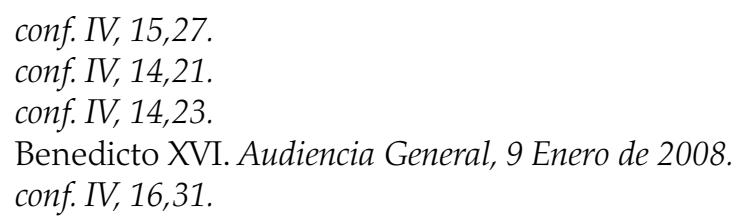


Según todo esto, y atendiendo al relato del libro IV de Confesiones, lo hermoso (pulchrum) sería lo que conviene consigo mismo, o sea, lo que por sí mismo agrada y es amable, por lo que el amor no sería sino la tendencia hacia lo bello. Mientras que lo apto aparecería como lo que conviene a otro ${ }^{98}$.

Por tanto, y siendo fiel a dicho criterio, en la idea de lo bello habría algo por sí y en sí, mientras que en lo apto tan sólo prevalecerá la utilidad. El goce estético deberá mostrarse desinteresado, pues de lo contrario no sería auténtico. Éste se adentra en el alma humana con el único fin de introducir en ella las ideas de unidad y discordia, análogamente a las de virtud y vicio.

De esta forma, lo bellamente estético sería aquello en donde se establece la unidad del espíritu en la virtud, mientras que lo antiestético reflejaría la virtud o vicio. Aquí, sentidos como el de la vista o el oído han de ser considerados superiores, pues en y a éstos se reduce el concepto de lo bello. No obstante, se ha de establecer una notable diferencia y separación entre lo que consideramos o designamos bello y lo qué es tenido como útil, pues -por ejemplo- el objetivo único del arte escultórico es la belleza y la diversión, e incluso algunas veces la utilidad cuando se trata de arte instructivo.

Pero, San Agustín -en su estudio sobre lo bello (hermoso) y lo apto- establece también una serie de propiedades objetivas a esta idea de belleza. Éstas serían:

1) La forma: Es aquella que otorga existencia y belleza a las cosas. Aparece como contraposición a la materia. Se encuentra (la forma) condicionada tanto por el espacio y el tiempo, así como determinada por el número. De esta forma, ambos (forma y número) derivan la idea de proporción, al menos en todas las cosas compuestas.

2) Para el obispo de Hipona es importante la relación establecida entre la igualdad y la semejanza, ambas ligadas a la simetría.

3) Como características menos importantes aparecen la distinción y el contraste.

4) Tanto la concordancia como la armonía deben existir.

Así, el resultado final de todas estas propiedades o condiciones objetivas no podrá ser otro que el orden, el cual hará posible la contemplación del Todo, hasta que sea engendrada la idea de Unidad, condición suprema para toda belleza.

Otras categorías más, en relación a lo bello, son lo conveniente y lo feo, el ser y el no-ser, por lo que nos hallamos ante una estética de la belleza vista en sí misma a la luz de la metafísica del ser. De esta forma, lo conveniente será aquello que tan sólo posea valor relativo, pues algo será apto o conveniente con relación a otro. Mientras lo feo no será sino aquello que se considera defectuoso,

98 conf. $I V, 13,20$. 
pues le falta la forma que lo determine, La fealdad absoluta, por lo tanto, no existe, aunque esta idea equivaldría a la nada, al no-ser.

En definitiva, nos encontramos ante un tratado $u$ opúsculo primerizo sobre el que resulta bastante complejo el realizar un análisis profundo, fundamentalmente por la pérdida del mismo (recordemos que fue redactado durante su etapa de profesión maniquea, por lo que podríamos fecharlo en el período comprendido entre los años 373 y 383/384). No obstante, y a pesar de todo ello, surgen estudiosos como Karel Svoboda (1938-2007) que intentan reconstruirlo.

Sin embargo, otros como Joseph Ratzinger (1927) creen que en dicho tratado de juventud, no se propondría más que un cambio y revisión del antiguo concepto griego de belleza:

"Agustín, quien en su juventud había escrito un libro sobre la belleza y la armonía, "De pulchroet apto", y era un enamorado apasionado de la belleza en las palabras, en la música y en la pintura, .ha considerado que la gran filosofía griega de la belleza... (era) dramáticamente cuestionada; lo que era bello, lo que significa la belleza tendría que ser debatido y experimentado nuevamente ${ }^{\prime \prime 99}$.

Pero, advirtamos que de éste tan sólo poseemos lo que el mismo obispo africano nos relata en sus Confesiones, por lo que nos resulta bastante extraño y complejo el entender esta"desidia y olvido" del hiponense por dicho tratado.

\section{LA MÚSICA: ARTE ENTRE LAS ARTES}

"Por generosa bondad de Dios fue concedida a los mortales, que tienen almas racionales, la música, esto es, el arte y el sentimiento de modular bien para amonestación de algo grande"100.

De entre todas las artes, el retórico africano siente una gran predilección y admiración por la música, como bien se puede desprender del texto anterior. Así, su tratado De música es un buen “botón de muestra" que refleja su capacidad para comprender y hablar sobre estética musical.

Gracias a dicha música se puede llegar a establecer la"simpatía o armonía" entre el alma humana y el mismo universo.

El diálogo mencionado anteriormente (De música) se enmarca dentro de la primera serie de escritos didácticos y filosóficos redactados, o al menos iniciados, "en los días tranquilos de Casicíaco"101, lugar en el que se ubicaba la casa de campo ("villa de Verecundo") en medio del bello paisaje lombardo cercano a Milán. El manual se compone de seis libros, los cuales fueron revisados nue-

99 Joseph Ratzinger."El sentimiento de las cosas y la contemplación de la belleza”, en Mensaje para Comunión y Liberación. Encuentro en Rimini (24-30 Agosto de 2002).

100 ep. 166, 13.

101 conf. IX, 4, 7-12, 
vamente por su autor durante su episcopado en Hipona. Ante todo, dicha obra desea transmitir conocimientos técnicos acerca del ritmo, el metro y el verso, al igual que la armonía (libro VI). Esta última queda reducida al mero número como elemento unitario que conlleva la medida y la cadencia, mientras el ritmo representa la medida de todo percibida tanto en la naturaleza exterior como en la propia audición. Por tanto, todo posee su propio ritmo.

Así, por ejemplo, el ritmo poético se apreciará de modo particular tanto en los tropos como en las alegorías.

Pero, debemos advertir que, en la antigüedad, el término"música" designaba y englobaba a las tres artes del movimiento, es decir, la palabra, el canto y la danza.

Aunque ya anteriormente San Agustín se hubo referido a la danza y al canto, sin embargo la presente obra que nos ha llegado solamente muestra a la palabra poética en su configuración tanto en metro como en verso. De esta forma, podríamos deducir que en el primitivo proyecto del santo se encontraría la elaboración de otros seis libros sobre la melodía y el canto -como él mismo lo cuenta a su amigo obispo Memorio- ${ }^{102}$. Estos nos habrían ofrecido ciertos conocimientos que, en la historia de la música antigua, han quedado perdidos definitivamente.

En cuanto al canto se refiere, su vivencia por vez primera en la iglesia de Milán por San Ambrosio (340-397) -la cual el obispo hiponense menciona en sus Confesiones ${ }^{103}$ - alentaron esta última intención (anteriormente señalada) del antiguo profesor de retórica. Pero, como él mismo diría:

"una vez que el peso de los asuntos de la Iglesia se ha echado sobre mis espaldas, escaparon de mis manos todas esas dulzuras" ${ }^{\prime 104}$.

Por otro lado, en la danza le otorga una gran importancia a la relación rítmica que existe entre el número espacial -o forma del cuerpo- y el movimiento -o movimiento corpóreo- No obstante, condenó enérgicamente todos los "espectáculos macabros" ${ }^{\prime 105}$ de su tiempo, fundamentalmente el drama -a pesar de que fue el teatro una de las grandes predilecciones de su juventud- ${ }^{106}$. Así, aquél conduce casi siempre al engaño y al error, mientras que la tragedia inspira una falsa piedad.

En definitiva, el presente tratado agustiniano se convierte en una"auténtica filosofía del ritmo universal" en el que para todos aquellos que posean unos ojos limpios y claros, palpitará el destello de la presencia divina, ya que dicha belleza no es otra cosa que la Verdad misma, es decir, Dios ${ }^{107}$ :

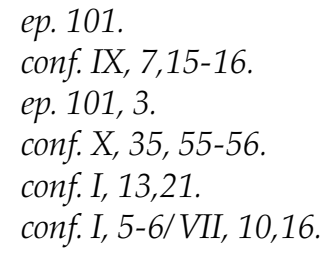


"Porque la belleza que a través del alma pasan a las manos del artista vienen de aquella belleza que está sobre las almas y por la cual suspira la mía día y noche" ${ }^{\prime 108}$.

Por tanto, el alma del artista tan sólo puede sentir o tomar su inspiración artística por participación en Dios, el verdadero Artista. Así, su creación es la fuente de donde mana toda belleza, toda armonía (belleza natural), como por ejemplo acontece con el canto del ruiseñor ${ }^{109}$. De esta forma, el alma del ser humano entra en conexión con el mismo universo, por lo cual podemos afirmar que "la música es el arte entre las artes", pues:

"Musica est scientia bene modulandi. An tibi non videntur?"110

\section{A MODO DE CONCLUSIÓN: ¿ÉTICA O ESTÉTICA?}

Llegados a este punto, hemos de plantearnos si en el arte agustiniano predomina más la estética en detrimento de la ética, o viceversa.

Así, dicha pregunta resultaría ser un tanto compleja el poder responderla desde nuestro contexto y punto de vista, es decir, el hombre actual -que vive inmerso en una sociedad fascinada y adormecida en lo puramente estético- resalta preferiblemente el orden estético que el ético.

De esta forma, el individuo necesita de lo bello -no así de lo recto y conveniente- para poder vivir "en calma". No obstante, y como bien nos indicará San Agustín, el concepto de belleza resulta ser algo análogo, nunca unívoco. Un claro ejemplo de ello lo tendríamos en el recién nacido, pues en él no será precisamente la forma estética lo que suscite el encanto y la fascinación de los hombres, sino -ante todo- la vida misma presente en el neonato.

Igualmente, podrá ocurrir con aquel individuo que -aunque externamente sea hermoso o bello- tal vez pueda ser en otros aspectos de su vida aborrecible y repugnante:

"Pues no toda masa corporal, aunque brillante con la luz visible, ha de estimarse mucho, si carece de vida, pues, por la ley natural, toda sustancia viva aventaja a toda sustancia muerta"111.

Por tanto, para"este gran santo y doctor de la Iglesia"112 la actividad estética entra dentro de la vida ética del hombre, pues -hemos de recordar que en el obispo hiponense- el arte es esencialmente ético.

108 conf. $X, 34,53$.

109 mus. I, 4,5.

110 mus. I, 2,2.

111 vera rel. 29, 52.

112 Benedicto XVI. Audiencia General, 9 Enero de 2008. 
De esta forma, es cómo su sistema estético resultará ser el más grande y completo de toda la antigüedad occidental, ya que en él hallamos un principio estético formalista, la valoración de la unidad orgánica, una división entre lo qué es la sensación y significación de toda obra artística, la concepción analógica de la belleza y, por último, la distinción entre la belleza natural y la artística.

No obstante, y como nos demostrará en el presente texto, para él la belleza moral siempre ha de ser exaltada sobre lo sensible:

“...siento que nuestras almas se mueven más ardiente y religiosamente en llamas de piedad con aquellos dichos textos sagrados, cuando son cantados de ese modo, que si no se cantaran así, y que todos los afectos de nuestro espíritu, en su diversidad, tienen en el canto y en la voz sus modos propios, con los cuales no sé por qué oculta familiaridad son excitados.

Pero aun en esto me engaña muchas veces la delectación sensual -a la que no debiera entregarse el alma para enervarse- , cuando el sentido no se resigna a acompañar a la razón de modo que vaya detrás, sino que por el hecho de haber sido por su amor admitido, pretende ir delante y tomar la dirección de ella. Así, peco en esto sin darme cuenta, hasta que luego me la doy.

Otras veces, empero, queriendo inmoderadamente evitar este engaño, yerro por demasiada severidad; y tanto algunas veces, que quisiera apartar de mis oídos y de la misma iglesia toda melodía de los cánticos suaves con que se suele cantar el Salterio de David, pareciéndome más seguro lo que recuerdo haber oído decir muchas veces del obispo de Alejandría, Atanasio, quien hacía que el lector cantase los salmos con tan débil inflexión de voz que pareciese más recitarlos que cantarlos.

Con todo, cuando recuerdo las lágrimas que derramé con los cánticos de la iglesia en los comienzos de mi conversión, y lo que ahora me conmuevo, no con el canto, sino con las cosas que se cantan, cuando se cantan con voz clara y una modulación convienentísima, reconozco de nuevo la gran utilidad de esta costumbre.

Así fluctúo entre el peligro del deleite y la experiencia del provecho, aunque me inclino más-sin dar en esto sentencia irrevocable-a aprobar la costumbre de cantar en la iglesia, a fin de que el espíritu flaco se despierte a piedad con el deleite del oído. Sin embargo, cuando me siento más movido por el canto que por lo que se canta, confieso que peco en ello y merezco castigo, y entonces quisiera más no oír al cantante"113.

Así, igualmente, a lo largo de la historia se ha propuesto varias veces dicha idea de considerar a lo estético como una mera preparación preliminar o fundamental de lo ético, es decir, que la formación adecuada de la sensibilidad artística es condición imprescindible para la formación moral.

Sin embargo, parece ser que fue el mismo Platón el primero que señalara este vínculo entre ética-estética, como bien señalara en este pasaje de su diálogo Protágoras (393-385 a. C): 
"Empezando desde la infancia, a lo largo de toda la vida les enseñan y aconsejan. Tan pronto como uno comprende lo que se dice, la nodriza, la madre, el pedagogo y el propio padre batallan por ello, para que el niño sea lo mejor posible, le enseñan, en concreto, la manera de obrar y decir y le muestran que esto es justo, y aquello injusto, que eso es hermoso, y eso otro feo, que una cosa es piadosa, y otra impía, y "haz estas cosas, no hagas esas". Y a veces él obedece de buen grado, pero si no, como un tallo curvado o torcido lo enderezan con amenazas y golpes.

Después de eso, al enviarlo a un maestro, le recomiendan mucho más que se cuide de la buena formación de los niños que de la enseñanza de las letras o de la cítara.

Y los maestros se cuidan de estas cosas, y después de que los niños aprenden las letras y están en estado de comprender los escritos como antes lo hablado, lo colocan en los bancos de la escuela para leer los poemas de los buenos poetas y los obligan aprendérselos de memoria.

En ellos hay muchas exhortaciones, muchas disgresiones y elogios y encomios de los virtuosos hombres de antaño, para que el muchacho, con emulación, los imite y desee hacerse su semejante.

Y, a su vez, los citaristas se cuidan, de igual modo, de la sensatez y procuran que los jóvenes no obren ningún mal. Además de esto, una vez que han aprendido a tocar la cítara, les enseñan los poemas de los buenos poetas líricos, adaptándolos a la música de la cítara, y fuerzan a las almas de sus discípulos a hacerse familiares los ritmos y las armonías, para que sean más suaves y más eurítmicas y más equilibradas, y con ella, sean útiles en su hablar y obrar. Porque toda vida humana necesita de la euritmia y del equilibrio"114.

No obstante, y a pesar de todo, surgen también aquellos que proponen la "idea extrema" de considerar a los valores estéticos por encima de todos los demás (éticos, etc). Sería ésta la postura mantenida por el llamado"esteticismo", la cual halló sus más fervientes adeptos, al menos, desde el Romanticismo.

Así mismo, sus más fieles defensores contemporáneos serán los"practicantes" de ciertas formas polémicas como el denominado body art ("arte corporal") y el arte conceptual.

En definitiva, la estética y la ética estarán siempre ligadas, pues sin ésta no existirá aquélla, ya que:

“La belleza es en un cierto sentido la expresión del bien, así como el bien es la condición metafísica de la belleza"115.

114 Protágoras 325c-326b.

115 San Juan Pablo II. Carta a los artistas, 4 Abril de 1999, punto 3. 


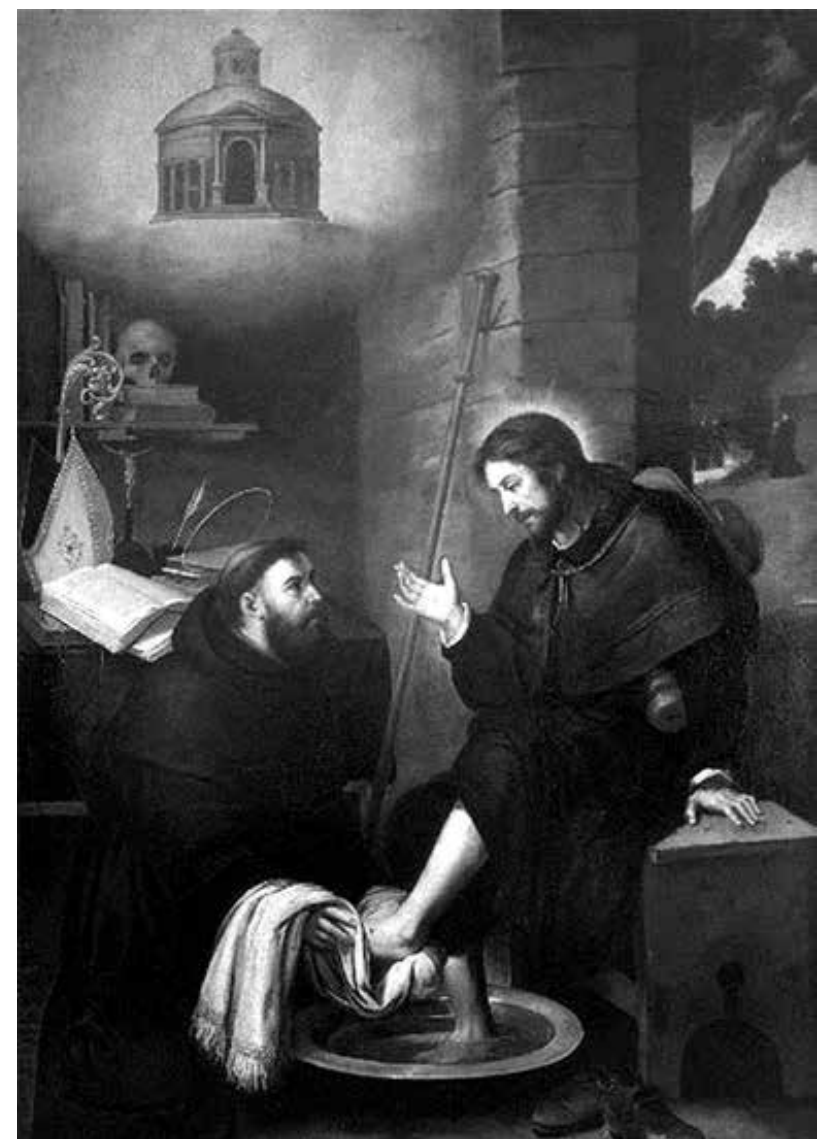

San Agustín lavando los pies a Cristo, Bartolomé Esteban Murillo, 1650-1655, Museo de Bellas Artes, de Valencia.

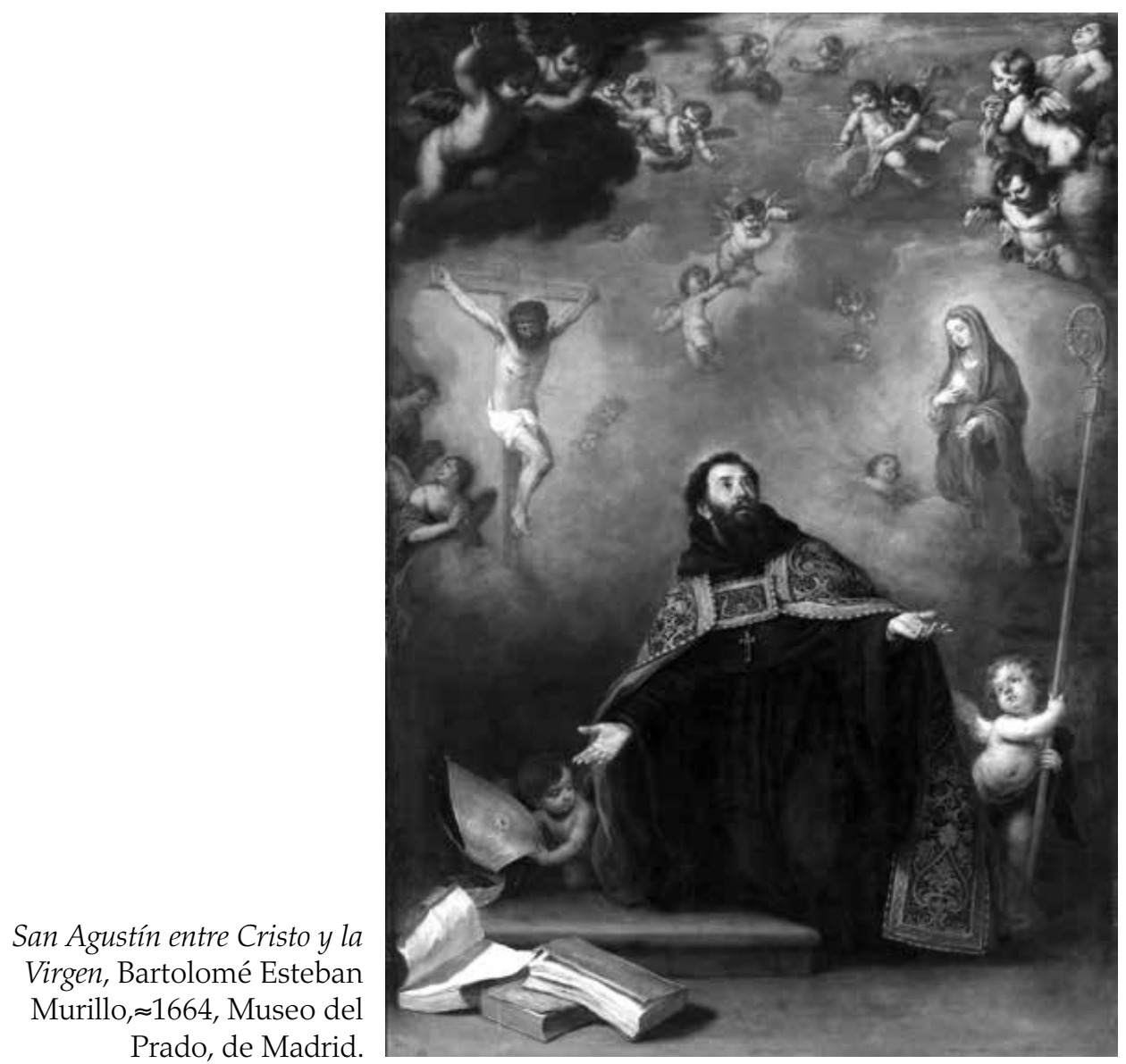



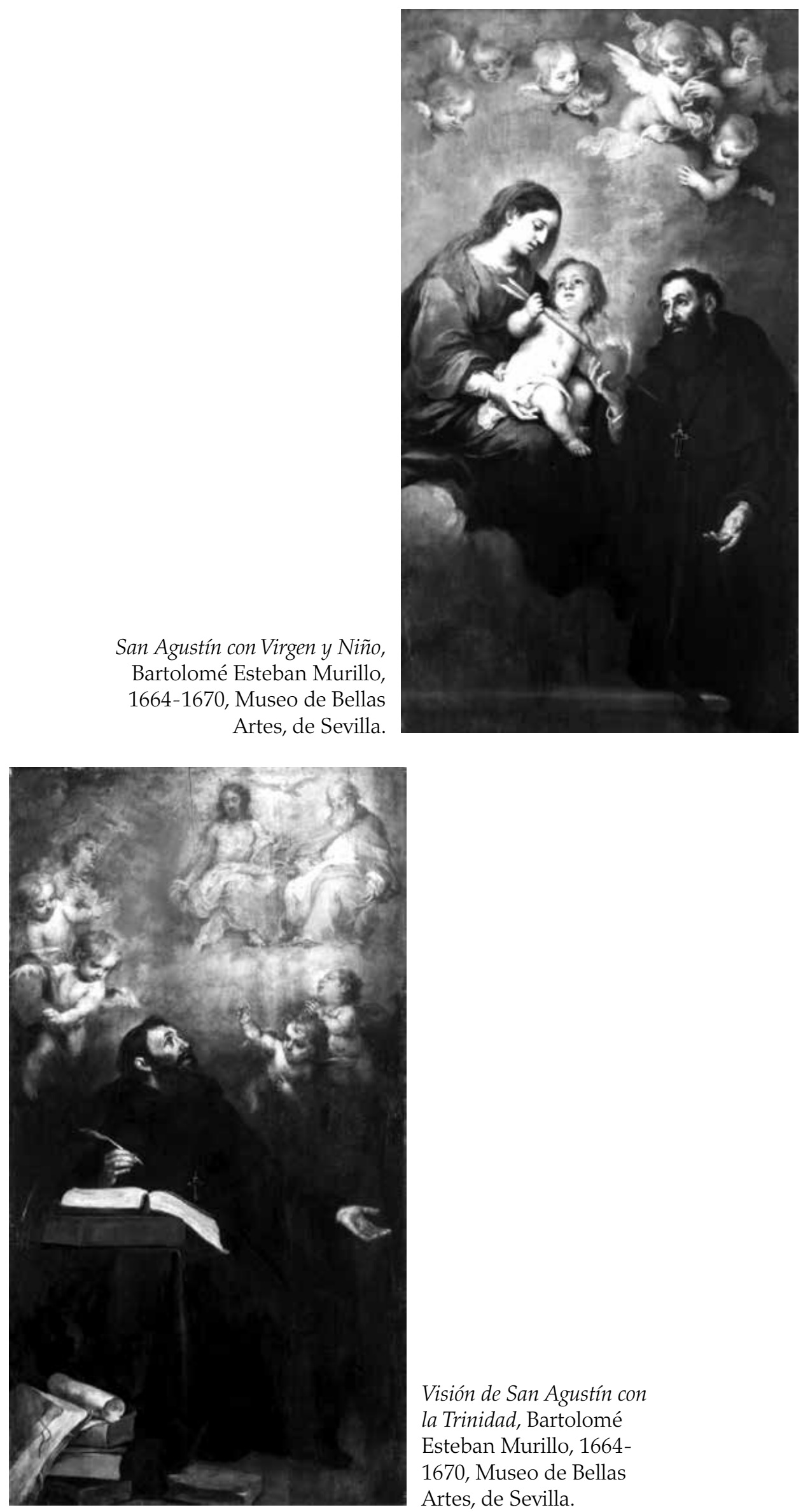

Visión de San Agustín con

la Trinidad, Bartolomé

Esteban Murillo, 1664-

1670, Museo de Bellas

Artes, de Sevilla. 


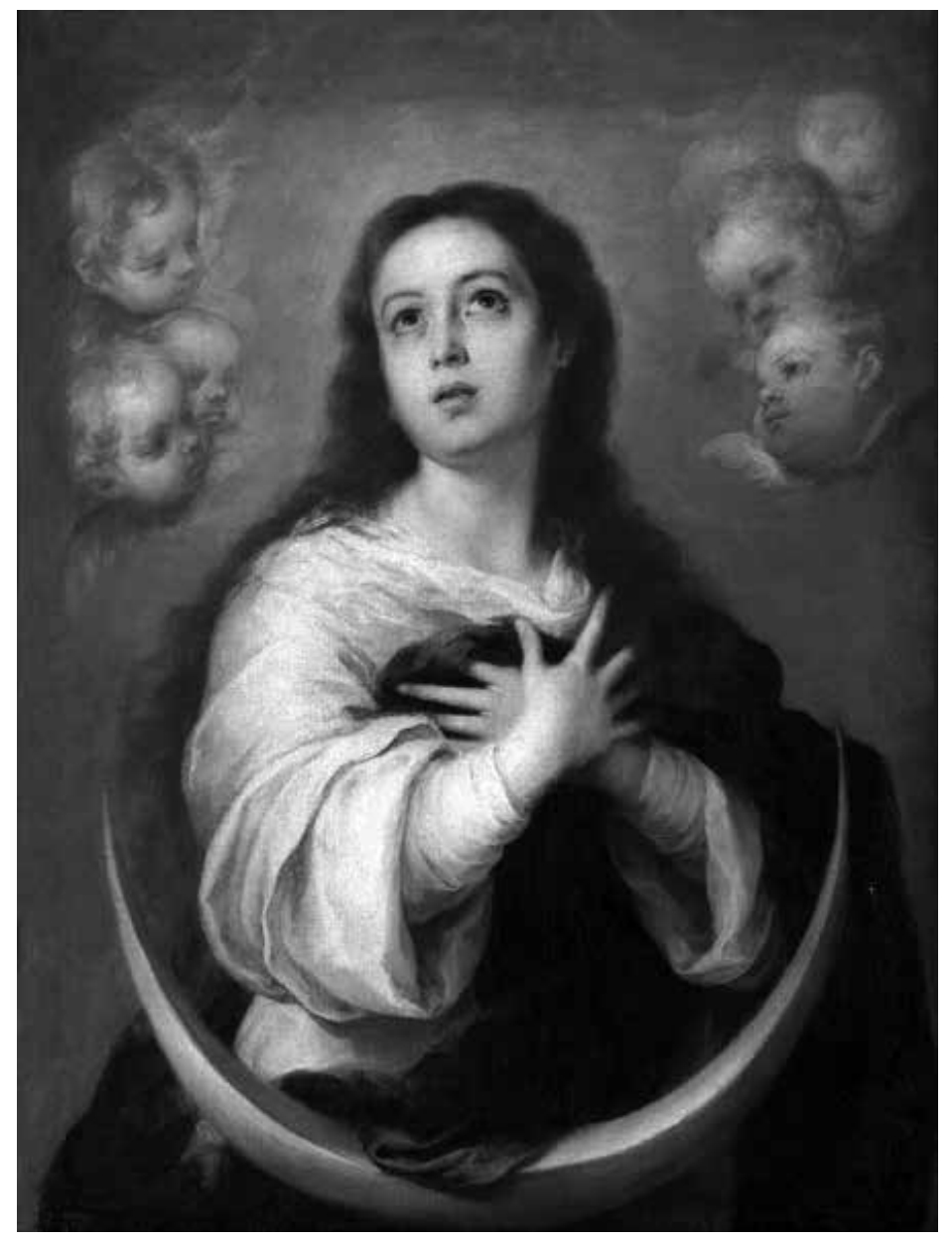

La Inmaculada Concepción, Bartolomé Esteban Murillo, $\approx 1665$, Museo del Prado, de Madrid.

"En lo tocante a los ojos, la congruencia razonable de las partes se llama belleza, y en lo relativo a los oídos, un concierto agradable o un canto compuesto con debida armonía recibe el nombre propio de suavidad. Pero ni en las cosas bellas, cuando nos agrada un color, ni en la suavidad del oído, cuando pulsando una lira suena clara y dulcemente, acostumbramos a decir que aquello es razonable. Para decir que la razón participa del placer de estos sentidos se requiere que haya cierta proporción y armonía".

(San Agustín de Hipona) 